\title{
Company + Farmer Leasing Analysis in Land Loss Mode
}

\author{
Jianjun Yu, Xiaoyong Huang, Xiaohuan Zheng, Qiangqiang Zhu \\ School of Business Administration, South China University of Technology, Guangzhou, China \\ Email: 1599488782@qq.com
}

How to cite this paper: Yu, J.J., Huang, X.Y., Zheng, X.H. and Zhu, Q.Q. (2017) Company + Farmer Leasing Analysis in Land Loss Mode. Open Journal of Social Sciences, 5, 217-224. https://doi.org/10.4236/jss.2017.510018

Received: September 20, 2017

Accepted: October 24, 2017

Published: October 27, 2017

Copyright $\odot 2017$ by authors and Scientific Research Publishing Inc. This work is licensed under the Creative Commons Attribution International License (CC BY 4.0).

http://creativecommons.org/licenses/by/4.0/

\section{cc) (i) Open Access}

\begin{abstract}
This paper mainly studies the rental selection of the company and the farmer in consideration of land loss. Among them, the leasing behavior is divided into long-term leasing and short-term leasing. Research has shown that land loss and default costs will affect whether the company and the farmer choose long-term leasing or short-term leasing. For the company, default cost is higher, the income will reduce, and then the company will choose long-term leasing mode. On the contrary, when land loss coefficient is larger, replacement land yields more, and then the company will choose a short-term leasing mode. For the farmer, when the high cost of default is paid by the company, he will choose short-term leasing. While land Loss is small, he will give priority to the long-term leasing.
\end{abstract}

\section{Keywords}

Company and Farmer Land Leasing, Land Loss, Default Costs, Long-Term Leasing, Short-Term Leasing

\section{Introduction}

At present, although there has been controversy about whether or not agricultural land has economy of scale, it has become possible to form land concentration and scale operation through land leasing market in eastern China. Due to the improvement of the southeast coastal area economy development of our country and accelerating of urbanization, the number of migrant workers gradually increased in recent years, and farmers reduced reliance on land, in a large number of unused farmland. These changes objectively create conditions for land consolidation and concentration, and the spread of agricultural mechanization also provided technical support for the expansion of farms, so the business model of the company leasing farmer's land has emerged. If land is idle, the far- 
mers get almost zero income from land. In this case, if the company gives farmer more rent than zero, the farmer will lease the land to the company for production. Based on the above social phenomenon, this paper mainly discusses the land lease of the company and the farmer.

Under the cooperation mode of "company + farmer", farmer and company organize production activities according to the contract form, which is a more advanced mode of production. Jia W.Q. (2005) thinks between farmer and company there is a principal-agent relationship. Although the relation is stable, the execution rate is lower under the influence of double moral. So establishing a long-term cooperation between farmer and company is a good way to solve these problems [1]. Ye F. (2011) analyzed the "company + farmers" type order agricultural supply chain coordination contract mechanism. In order to solve the problem of lower order execution rate of agriculture, he proposed a coordinating-contract type of "purchase subsidy + market protection price + margin" [2]. From the perspective of asymmetric contract capital, symmetric transaction form and whole value chain, Mi, Y.S. and Luo, B.L. (2009) analyzed the self-implementation and decision-making process of "company + farmer" as the maximization of revenue [3]. Pu, X.J., Fang, W.D. and Wu, Y. (2016) analyzed the influence of the degree of risk aversion and the proportion of income sharing on the choice of model, and thought that under the mode of "company + farmer" mode, the level of effort is higher than that of the loose type, and it can further improve the level of supply of supply chain [4]. Hu, K. and Gan, Y.Q. (2013) introduced mass production into the supply chain decisions and discussed how to control the production scale of farmer by company, and how to make decisions can ensure the quality of the products under reasonable income of the farmer [5].

In the aspect of land leasing, Chen, C.Y. (2010) found that the supply and demand of rural areas are the two key factors influencing the agricultural land transfer rents, while the other factors have been achieved through supply and demand [6]. Zhang, P.L., Gao, J. and Quan, Y. (2010) through the study, believed that raising the capital yield of farmland and reducing the transfer rent price of the contracted land are two important methods to promote farmland transfer [7]. From the theoretical perspective, Fang, Z.Y. (2008) analyzed that the formation of farmland transfer equilibrium price is the result of the interaction between supply and demand in farmland transfer process [8]. Jiang, S.B. and $\mathrm{Su}, \mathrm{Q}$. (2003) pointed out that currently agricultural land use fragmentation affects the full flow of agricultural land between different USES, resulting in the separation of farmland rent distribution and limiting the efficiency of land [9]. Huang, L.P. (2005) pointed out that the reasons for the low circulation of the right of use and management of farmland in China is Suppliers' preference and motivation, lack of technological innovation in agricultural production, the outflow of agricultural capital, high production cost and economy of scale, and so on [10]. 
In general cognition, the planting of agricultural products has the loss of land, so planting land needs to consider the effect of fallow period. Every planting can be thought of as the land of a consumer, the company signed with the farmer land lease agreement to consider wreck coefficient, and higher wreck will affect companies decided to pay the rent. In the land lease mode, there are two modes of long-term leasing and short-term leasing. The company does not blindly follow the contract to enforce the rental process, sometimes as the market changes he may break a contract and adjust leasing strategy. Therefore, it is necessary to study the long-term leasing or short-term leasing selected by the company and the farmer. In this paper, the study of the farmer for the lease behavior must satisfy the classical game theory. It must satisfy two constraints, namely the constraint and incentive compatibility constraint. In this case, the cost of the leased land cannot be higher than the original planned cost for the company, and the land rental income must be higher than the income derived from the direct selling of the land for the farmer. We divide the lease into long-term leasing and short-term leasing, and use quantitative methods to study the rental options of the company and the farmer.

\section{Model Building}

Let's say the price function is $P(i, j, k)$. Among them, " $i$ " stands for the quality level of the land, which is assumed to have five kinds of rich, good, general, low and poor, and the higher $i$ value, the lower the land quality. The parameter " $j$ " denotes the lease time of the land. And the parameter " $k$ " represents the time of use of the land. $K$ is calculated in the unit year, and when $k=0$, the land that is not leased by other people in the $j$ year; When $k$ is not zero, the value of the land that is leased in the year of $j$ is the price of the land after $\mathrm{k}$ years. We assume the following relationship between the parameters:

$$
\begin{array}{r}
p(i+1, j, k)=l * p(i, j, k) \\
p(i, j+1, k)=m * p(i, j, k) \\
p(i, j, k+1)=\left\{\begin{array}{l}
u * p(i, j, k) \\
v * p(i, j, k)
\end{array}\right.
\end{array}
$$

Among them, obviously the parameters are satisfied:

1) " $P$ " represents the price relationship between land and quality level of $i+1$ in $j$-year lease; $0<l<1$.

2) " $m$ " represents the land of grade $i$, the relationship between the rent of $j$ year and the rent of $j+1 ; 0<m$.

3) " $u$ " represents that in the cognition of peasant households, the price relationship between used $k+1$ year and $\mathrm{k}$ year in $j$-year lease; $0<u<1$.

4) " $V$ " represents that in the cognition of the company, the price relationship between used $k+1$ year and $\mathrm{k}$ year in j-year lease; $0<v<1$ and $0<v<u<1$.

At the same time, it is assumed that the maximum use of each land will be 4 years, and 4 years later the farmer will cultivate, fallow or change a new compa- 
ny for leasing cooperation. The income derived from land about cultivation or other activities of farmers is $N$. The income earned by the company through the lease of land is $s * P(j, j, k)$, while the income from the land acquisition of farmers is $r * P(j, j, k)$. In the process of using and leasing, farmer cannot sell $100 \%$ according to the valuation, and the specific price is correlated with the price of the parameters.

1) long-term leasing: the company takes the form of leasing and uses the land directly, and then turns out after four years.

The land of grade $i$ is used by the company in $j$-year, then is transferred out four years later. The needed input of the company is:

$$
T_{I}=r \sum_{k=0}^{3} P(i, j, k)=r\left(1+v+v^{2}+v^{3}\right) * P(i, j, 0)
$$

The income of the company is:

$$
T_{2}=s\left(1+v+v^{2}+v^{3}\right) * P(i, j, 0)
$$

So the profit of the company is:

$$
T_{3}=(s-r)\left(1+v+v^{2}+v^{3}\right) * P(i, j, 0)
$$

2) Short-term leasing: The company rents out land for a certain state.

In order to guarantee the improvement of land revenue, company hopes to be able to continually the best land leasing, so that it may choose to rank for $i$ land leasing. A year after back, it will choose the high quality of land again. At this time, finding a new land cost is higher for the $O$, so the needed input of the company is:

$$
T_{6}=r \sum_{j=1}^{4} P(i, j, 0)+4 O
$$

The income of the company is:

$$
T_{7}=s \sum_{j=1}^{4} P(i, j, 0)
$$

So the profit of the company is:

$$
T_{8}=(s-r)\left(1+m+m^{2}+v m^{3}\right) * P(i, j, 0)-4 O
$$

At this point, the farmer will receive a year's rental income and the default income, and the remaining three years will need to be obtained through his own cultivation:

$$
T_{9}=r * P(i, j, 0)+O+3 N
$$

3) No leasing: the farmer does not lease the land in the year of $j$ and has just fallow the land, and has obtained the proceeds by himself in 4 years:

$$
T_{5}=4 N
$$

On the contrary, the income that farmer can obtain when he leases the land for 4 years is:

$$
T_{5}=r\left(1-u^{3}\right) * P(i, j, 0)
$$

\section{Model Analysis}

From the second quarter of the model, we can draw the following conclusions: 
For the company, the land value is higher, and land loss is big, the short-term rental companies preferred. Only when the land loss is small, the company chooses long-term leasing. For the farmer, when the cost of leasing is higher, the land loss is small, the farmer chooses to take the form of leasing. When the cost of default is high, the farmer chooses short-term leasing. When land loss is small, the farmer chooses long-term leasing.

1) For the company, he has two different ways to choose, one is a long-term leasing for four years, another kind is to choose the best land lease for four years, in which assuming began leasing term is 1 year. Compare the benefits of the two approaches, if long-term leasing is better than short-term leasing, that means:

$$
T_{3}>T_{8}
$$

We can get:

$$
m-v<\frac{4 O}{P(i, 1,0)(s-r)\left(1+m+v+m v+m^{2}+v^{2}\right)}
$$

On the contrary, if short-term leasing is better than long-term leasing, we can get:

$$
m-v>\frac{4 O}{P(i, 1,0)(s-r)\left(1+m+v+m v+m^{2}+v^{2}\right)}
$$

According to the result, when the cost of punishment is higher, the company will be more satisfied (12). According to the assumption that the land market change index is higher than the loss of land, when punishment cost is higher, each time replacing land will cause bigger loss, the company in terms of income will choose long-term leasing.

When the value of land is high, the company will choose short-term leasing, because the value of land is higher, and the benefit from quality land is greater. At this point, if the market has little impact on the land value, the company will choose to take the risk of default, change the land for planting, and then reap the benefits. In the same way, if the benefits of land become larger, it will also lead to companies switching to different companies for leasing, which also explains that even in the leasing mode the company will default to the farmer.

When the market influence factors $\mathrm{m}$ is larger, the market bullish on land resources, leading to loss of land influence is negligible relative to the market, short-term leasing relative to long-term leasing more efficient at this moment, defaults are more likely to happen. When the land loss is very small, the correlation coefficient $\mathrm{v}$ is close to the market factor $\mathrm{m}$, the value of long-term leasing is higher, so the company will choose the form of long-term leasing.

2) For the farmer, there are three conditions, which are completely non-leasing, lease a year, and long-term leasing. First, consider the difference between renting and not renting, when the farmer chooses to rent:

$$
\min \left(T_{9}, T_{1}\right)>T_{5}
$$

Because of the analysis of farmers, the loss of land determined is change from 
the company to the farmer. The solution is:

$$
r * P(i, 1,0)+O>N \text { or } \frac{r * P(i, 1,0)\left(1+u+u^{2}+u^{3}\right)}{4}>N
$$

When the cost of default and the cost of lease and the land loss are higher, the farmer chooses the form of leasing, because the self-cultivation is not only high risk but also low income. Similarly, if the cost of default compensation is higher, meeting $O>r\left(1+u+u^{2}+u^{3}\right) * P(i, j, 0)-3 N$, the farmers will choose short-term leasing. When the discount coefficient of the leased land is not high, meeting $O<r\left(1+u+u^{2}+u^{3}\right) * P(i, j, 0)-3 N$, the farmers will choose long-term leasing.

Comprehensive analysis, the company and the farmer also choose long-term leasing must have:

$$
m-v<\frac{4 O}{P(i, 1,0)()(s-r)\left(1+m+v+m v+m^{2}+v^{2}\right)}
$$

and

$$
O<r\left(1+u+u^{2}+u^{3}\right) * P(i, j, 0)-3 N
$$

From the hypothesis, we can get :

$$
m>u>v>m-\frac{4 O}{P(i, 1,0)(s-r)\left(1+m+v+m v+m^{2}+v^{2}\right)}
$$

It means that only when the quality of land is high and the annual discount is very low, both the company and farmer have a better choice of long-term leasing mode.

On the contrary, the company and the farmer also choose short-term leasing must have:

$$
m-v>\frac{4 O}{P(i, 1,0)(s-r)\left(1+m+v+m v+m^{2}+v^{2}\right)}
$$

and

$$
O>r\left(1+u+u^{2}+u^{3}\right) * P(i, j, 0)-3 N
$$

In this situation, the consumption rate of land loss is higher, and farmer are more likely to harvest themselves, both the farmer and company will be able to choose short-term leasing.

\section{Numerical Validation}

Next, we further validate the inferences by example analysis. According to the results of model analysis, we have several basic factors in digital assignment to research that whether or not different digital assignment under the condition of the company and the farmer's income decision is consistent with the model of research results. The numerical hypothesis and simulation are as follows:

1) In the case $1:$ 


$$
\begin{gathered}
P(1,1,0)=1000, m=0.6, u=0.5, v=0.4, O=600, r=0.5, N=1200, s=0.9 \\
\frac{4 O}{P(i, 1,0)(s-r)\left(1+m+v+m v+m^{2}+v^{2}\right)}=0.203>m-v=0.1
\end{gathered}
$$

For the farmer, the income gained from long-term leasing is 9375, from renting 1 year and growing by himself 3 years is 9200 and from growing 4 years by himself is 4800 . Obviously long-term leasing get higher yield. For the company, the long-term leasing income is 6496, while the short-term leasing income is 6304. The long-term leasing income is greater than the short-term leasing income.

2) In the case 2 :

$$
P(1,1,0)=1000, m=0.6, u=0.5, v=0.4, O=600, r=0.5, N=1300, s=0.9
$$

When the self-cultivation income increases, that means $\mathrm{N}$ changes from 1200 to 1300 , we can see that the long-term leasing income of the company is 6496 , and the short-term leasing income is 6304 . He will still choose long-term leasing form for production. In the perspective of farmers, his long-term leasing income is 9375 , short-term leasing is 9500 , and growing by himself income is 6500 . The farmer would rather company pay liquidated damages of breach of contract, while the company is willing to reap the benefits of lease over a long period of time, the two sides will appear contradictory.

3) In the case 3:

$$
P(1,1,0)=1000, m=0.6, u=0.5, v=0.3, O=600, r=0.5, N=1300, s=0.9
$$

When the discount rate of land increases, the year-on-year value decreases, that means $\mathrm{v}$ changes from 0.4 to 0.3 , the long-term leasing income of farmers is 9375, and the short-term leasing income is 9500. The long-term leasing income of the company is 5668, and the short-term leasing income is 6304 . Because of the short-term leasing income is greater than the long-term leasing income, the company and the farmer will choose the short-term leasing, which is consistent with the analysis above.

\section{Research Conclusions}

This paper mainly studies the relationship between land loss coefficient and long-term leasing or short-term leasing. The results show that for the company, when the penalty cost of default is higher, the frequent change of land will cause the company more losses, and the company will choose the long-term leasing model from the income perspective. While the value of land is higher and the income from quality land will be greater, the company will choose short-term leasing and replace the land for planting, so he can benefit. For the farmer, when default cost and rental costs are high, land loss farmers will choose to lease mode. And when the company pays default compensation cost is high, the farmer will choose short-term leasing. While land wreck is small, he will be preferred to consider long-term leasing. From what has been discussed above, when the land loss rate is low, the company and the farmer will choose the long-term 
leasing. With the improvement of self-cultivation ability and the increase of land loss, the company and farmer will choose short-term leasing. Moreover, when the cost of default is high, the farmer will give priority to short-term leasing.

Through the discussion of this question, we deeply understand the decision choice of the company and the farmer under the lease mode considering the loss of land. It can help company and farmer effectively cope with the external environment changes, the dynamic changes for the current international market under the background of agricultural production has important theory meaning and realistic meaning, which can effectively deal with the agricultural industry development faced by many risk factors in the process of transformation and upgrading, so as to further promote the level of agricultural rapid ascension.

\section{Acknowledgements}

This project is supported by national natural science foundation of China (71071059), the fundamental research funds for the central universities (2015QNXM13, 2017X2D14).

\section{References}

[1] Jia, W.Q. and Jia, R.A. (2005) The Company and Farmer in the "Company + Farmer" Model Based on the Explanation of the Principal-Agent Theory. Chinese Rural Economy, 8, 34-37.

[2] Ye, F., Lin, Q. and Li, Y.N. (2011) “Company + Farmer” Order Agricultural Supply Chain Coordination Contract Mechanism Based on CVaR. Theory and Practice of Systems, 3, 450-460.

[3] Mi, Y.S. and Luo, B.L. (2009) The Contract Capital Asymmetry, the Transaction Form of the Inverse String and the Value Chain Income Distribution: The "Company + Farmers" Model of the Temperature Model. China's Rural Economy, 8, $12-23$.

[4] Pu, X.J., Fang, W.D. and Wu, Y. (2016) Under Different Contracts, Farmers and Companies are Engaged in Research. Journal of Systems Engineering, 2, 242-253.

[5] Hu, K. and Gan, Y.Q. (2013) Study on the Optimal Feeding Scale of Farmers in the Supply Chain of "Company + Farmers" Mode. Theory and Practice of Systems, 33, 1200-1206.

[6] Chen, C.Y. (2010) Research on the Theory and Method of Agricultural Land Price Evaluation.

[7] Zhang, P.L., Gao, J. and Quan, Y. (2010) Economic Analysis of Rural Land Circulation. Anhui Agriculture Report, 11, 110.

[8] Fang, Z.Y. (2008) Study on the Mechanism of the Main Transfer MechanismNanjing City for Example.

[9] Jiang, S.B. and Su, Q. (2003) Land Transfer "Rent Stratification" Phenomenon and its Root Causes. Problems of Agricultural Economy, 4, 42-48.

[10] Huang, L.P. (2005) Discussing the Reasons for the Low Circulation Prices of Rural Contracted Land Use Rights. 